\title{
A Case Study of Group Counseling for the Individuation of Middle-aged Women
}

\author{
Joo Hyun Shin ${ }^{1}$, Eun Sil Kim² \\ ${ }^{1}$ Ph.D, Addiction Rehabilitation Counseling, Namseoul University Graduate School, Korea, \\ findingflow5@gmail.com \\ ${ }^{2}$ Professor, Department of Child Welfare, Namseoul University, Korea, gender@hanmail.net
}

Corresponding author: Eun-sil Kim

\begin{abstract}
In this study, group counseling was conducted in the perspective of Jung's analytical psychology for self-growth of middle-aged women, and its effects on their individualization process were examined. The group counseling was a process of self-realization to meet one's true-self through the analysis of one's persona and complex in the unconscious, and was conducted twice a week for 60 minutes from April 5th to May 24th, 2021, for a total of 16 sessions in the form of non-face-to-face ZOOM meetings due to COVID-19. The works of each session were analyzed in the perspective of analytical psychology, and the Sacks Sentence Completion Test was conducted afterwards. The results of this study demonstrated that the psychological crises of middle-aged women showed a strong identification with their personas of their early lives and that they were isolated from their own self, blocked from their own inner world. In the sentence completion test, each participant's attitude toward her original family exhibited a change from a negative response to a positive acceptance. In other words, group counseling enabled the participants to gain awareness of and connect with their unconscious, thereby facilitating the process of curative individualization.
\end{abstract}

Keywords: Middle-aged Women, Group, Counseling, Individualization, Program

\section{Introduction}

\subsection{The Need for Research}

The middle age is a period when individual differences gradually appear, and individuality is shaped by different experiences. That is, while the middle age may be a period of relatively stable and comfortable living, it may be a period of struggle for others who face problems such as failure of goals, frustration, unemployment, health problems of themselves and their families, conflicts with their adolescent children, divorce, spouse's death, or parents' death[1]. Even with the presence of such difficulties, middle age is a step that enables oneself to pay greater attention to the inner world than the outer world and achieve self-realization through the process of individualization. This is because the opportunity for self-realization comes when you experience different types of pain and mental crises [2]. The process of self-realization requires considerable conscious effort, such as recognizing and accepting one's inferiority, pain and scars, and desires and non-desires, and making choices and taking on challenges. In other words, seeing oneself is an uncomfortable and difficult process. Therefore, there are people who cannot pursue self-realization and many who reject it. Personality can be called self-

Received: July 19, 2021; $1^{\text {st }}$ Review Result: September 06, 2021; $2^{\text {nd }}$ Review Result: October 20, 2021 Accepted: November 30, 2021 
realization as it becomes its original self. It is to become a complete me by exerting and integrating all of my spirit from birth into the world[3].

Jung's personalization process refers to the process of realizing oneself by conscientising and integrating unconsciousness. Here, "self" is the central atom of the mind as well as one's totalness, which includes both consciousness and unconsciousness [4]. Our minds are made up of the minds we know, that is, unconsciousness, and unconsciousness can be divided into individual unconsciousness and collective unconsciousness. If you take a closer look at the world of consciousness and unconsciousness, you can see Ich, ego in the consciousness world depending on its characteristics and function, and the unconscious world has unique elements called shadow, anima, animus, and self [5]. However, unconsciousness cannot be totally conscientised, and as there are many things whose depths and nature are still unknown, complete self-realization is virtually impossible. Therefore, Jung said that selfrealization is necessarily "being intact" rather than "being complete" [6].

According to previous studies [7] [8] [9] the process of individualization is the process of recognizing the dark side of the ego, that is the shadow, and connecting the alienated animus to the negative animus, through the inspection of persona according to the structure of the mind. In other words, it is the process of individualization to realize the totality of one's consciousness and unconsciousness and to live as a true self.

In this study, in order to facilitate the individualization of middle-aged women, group counseling was conducted to enable them to deal with "persona," "complex," and "shadow," one of the unconscious mental factors that the self cannot control. Art activities were mainly utilized, as the expression of art is the product of the reaction of consciousness by actively objectifying unconsciousness and is the result of the collaborative work of consciousness and unconsciousness [10].

Programs for individualization of middle-aged women use various media such as Mindfulness Meditation Program [11], and programs incorporated with fairy tales and stories to express one's inner state [12]. In this study, various methods, such as writing, painting, and meditation techniques, were used to bring up unconscious images to the conscious level, shape them, and help explore the inner surface.

\subsection{The Purpose of the Study}

This study attempted to qualitatively analyze the group counseling process based on analytical psychology for the individuality of middle-aged women. In this study, qualitative research was used to conduct research on the process of personalization of middle-aged women. The reason for adopting the qualitative research method was that this study was conducted based on experience in the counseling field, and it was an appropriate research method in that participants focused on and understood the meaning and nature of the group counseling experience in the individualization process.

First, the process of change in individualization of middle-aged women who participated in the group counseling based on analytical psychology was examined.

Second, the process of change of individualization of middle-aged women was analyzed through activity works and content analysis.

\section{Research Methods}

\subsection{Participants in the Study}

\subsubsection{Participant A}

Participant A is a 50-year old doctorate student, counselor, and mother who experienced pressure and physical as well as emotional exhaustion from those roles. Although she was the second oldest child in 
a family with many children, she struggled for approval and readily took on the role of the eldest child, helping her family and people around her in order to confirm her existence. However, she has recently started to experience anxiety and depression.

\subsubsection{Participant B}

Participant B is 58 years old and works as a Ph.D. and counselor at the Graduate School of Counseling, but she lacks confidence in everything, and has been experiencing lethargy and exhaustion. She says she doesn't seem to have a big problem, but on the other hand, she has the dual desire to explore the fundamental causes of exhaustion and lethargy. In a group setting, her speech was characterized with repetition and a lengthy and unilateral way of communication.

\subsubsection{Participant C}

Participant $\mathrm{C}$ is 59 years old and has been working as a counselor for 15 years, but she is unable to concentrate on her work and lacks confidence as a counselor. In particular, she talked about the environment she grew up in, where she could not get what she deserved if she was not stubborn enough in the presence of many siblings, and expressed her desire to restore confidence through counseling.

\subsection{Measuring Tools}

First, as a method of case study, paintings and writings done during group counseling sessions as well as verbatim recordings of each session were used to analyze their key symbolic meanings, rather than hypothesis or verification through technical statistics.

Second, Sacks (1950)'s[13], adult sentence completion test is a total of 50 questions, consisting of four sub-regions: family, sex, interpersonal relationships, and self-concept. In this study, it was used to explore the changes in images of "Image of One Family", "Image of One's Ability", and "Image of Future and Goal".

\subsection{Data Collection and Method}

The purpose of this study was notified on BAND after which voluntary participants were recruited, whose written consents were obtained. Two weeks before the group counseling, the motivation and purpose of participation were verbally described, and the basic information of participants was collected. From April 2021 to the end of May 2021, the group counseling was held once a week for 60 minutes, twice a week, for a total of 16 sessions. Collective consultation was conducted with non-face-to-face ZOOM video sessions due to COVID-19, and detailed records, recordings, and pictures of all sessions were collected. Based on the collected data, data were qualitatively analyzed from the perspective of the individualization process through books and literature related to analytical psychology, and content validity was secured through triangular verification by one counselor and fellow counselors.

\subsection{Composition of a Group Counseling Program}

The program consisted of 16 sessions for the individualization of middle-aged women. In order to extract the compositional area and sub-elements of the individualization process through analysis psychology, previous studies [9] [7] [8] [14]. were referenced. Finally, the program was applied step by step based on the analysis psychology theory as a program component, and it consisted of symbolization of unconsciousness, consciousness of unconscious work, expansion of unconsciousness and consciousness, and integration into self. In addition, the sub-elements and contents to be discussed in each composition area were composed of persona, shadow, and complex. For the composition area 
and sub-factors, one counseling expert professor and one counseling doctoral student were consulted twice for revision and supplementation.

The specific contents of the group program are as follows.

The 1st and 2nd sessions consisted of relaxation experience, relationship connection among the participants, and a self-exploration process at the conscious level. In the 3rd and 4th sessions, the members' inner needs were identified, and the process of distinguishing themselves from persona, a social personality, was conducted through painting work. During the mid-term phase of the 5th to 6th sessions, internal symbols were projected through meditation to meet shadows, and during the 7 th to 8 th sessions, the consciousness of shadows projected outward was explored. In the 9th and 10th sessions, fairy tales were used to track the causes of inferior complex suppressed through fairy tale characters, providing opportunities to meet oneself who did not want to face and to think about the process of overcoming negative emotions from various perspectives. In addition, in the process of analyzing the story, one was able to objectify one's appearance through role-playing, and meditation, fantasy, drawing, and play allowed for the revelation of one's inner image.

In the 11th and 12th sessions, word association projection tests were conducted for the projection and reflection of psychological and internal emotional complexes that were not easily revealed as a defense of the unconscious area, thus facilitating communication with the inner side through connection with the unconscious. In the 13th and 14th sessions, participants had the opportunity to discover one's own positive energy inherent in the complex, and in 15th and 16th sessions, they had the opportunity to hope for a life true to themselves as they put together the process of self-awareness and general unconsciousness. Specific program contents are shown in [Table 1].

[Table 1] Group Counseling Program for the Individuation of Middle-aged Women

\begin{tabular}{|c|c|c|c|c|c|}
\hline Stage & Components & Session & Topic & Session Objectives & Contents of activities \\
\hline \multirow{3}{*}{ Primary } & \multirow{3}{*}{$\begin{array}{c}\text { Symbolization } \\
\text { of } \\
\text { unconsciousness }\end{array}$} & & Primary session & $\begin{array}{l}\text { Understanding the } \\
\text { goals and operation } \\
\text { methods of the program }\end{array}$ & $\begin{array}{l}\text { - Individual interviews for } \\
\text { individual case concepts }\end{array}$ \\
\hline & & $\begin{array}{l}1 \\
2\end{array}$ & $\begin{array}{c}\text { Self- } \\
\text { symbolization }\end{array}$ & $\begin{array}{l}\text { - Form intimacy } \\
\text { - Expanding the scope } \\
\text { of self-consciousness }\end{array}$ & $\begin{array}{l}\cdot \text { Creating nickname } \\
\text { - Expressing one's } \\
\text { symbol } \\
\text { - Sharing one's symbol }\end{array}$ \\
\hline & & $\begin{array}{l}3 \\
4\end{array}$ & Persona & $\begin{array}{l}\text { - Raising } \\
\text { consciousness about } \\
\text { persona }\end{array}$ & $\begin{array}{l}\text { Expressing one's persona } \\
\text { in a picture } \\
\cdot \text { Exploring one's social } \\
\text { role }\end{array}$ \\
\hline \multirow[b]{2}{*}{$\begin{array}{l}\text { Middle } \\
\text {-former }\end{array}$} & \multirow{2}{*}{$\begin{array}{c}\text { Raising } \\
\text { consciousness } \\
\text { about } \\
\text { unconsciousness }\end{array}$} & $\begin{array}{l}5 \\
6\end{array}$ & Shadow & $\begin{array}{l}\text { Shadow projection } \\
\text { through the symbol of } \\
\text { inner form }\end{array}$ & $\begin{array}{l}\text { - Shadow search through } \\
\text { meditation } \\
\text { - Attempt to communicate } \\
\text { with shadows }\end{array}$ \\
\hline & & $\begin{array}{l}7 \\
8\end{array}$ & Shadow & $\begin{array}{l}\text { - Shadow projected } \\
\text { outward }\end{array}$ & $\begin{array}{l}\text { - Exploring life that one } \\
\text { has not lived as oneself } \\
\text { through meditation } \\
\text { - Raising consciousness } \\
\text { about oneself projected to } \\
\text { others }\end{array}$ \\
\hline $\begin{array}{l}\text { Middle } \\
\text {-latter }\end{array}$ & $\begin{array}{l}\text { Expression of } \\
\text { unconsciousness } \\
\text { and expansion of } \\
\text { consciousness }\end{array}$ & $\begin{array}{c}9 \\
10\end{array}$ & $\begin{array}{l}\text { Shadow and } \\
\text { Complex }\end{array}$ & $\begin{array}{l}\text { Exploration of complex } \\
\text { in shadow }\end{array}$ & $\begin{array}{l}\text { - Explore complex in fairy } \\
\text { tales } \\
\text { - Raising consciousness } \\
\text { about memories, } \\
\text { emotions, situations, and } \\
\text { characters }\end{array}$ \\
\hline
\end{tabular}




\begin{tabular}{|c|c|c|c|c|c|}
\hline & & $\begin{array}{l}11 \\
12\end{array}$ & $\begin{array}{l}\text { Shadow and } \\
\text { Complex }\end{array}$ & $\begin{array}{l}\text { - Raising consciousness } \\
\text { about complex in } \\
\text { shadow }\end{array}$ & $\begin{array}{l}\text { - Raising consciousness } \\
\text { about the expressions of } \\
\text { one's unconscious } \\
\text { complex through word } \\
\text { association tests }\end{array}$ \\
\hline \multirow[b]{2}{*}{ Closing } & \multirow[b]{2}{*}{$\begin{array}{l}\text { Integration into } \\
\text { oneself }\end{array}$} & $\begin{array}{l}13 \\
14\end{array}$ & $\begin{array}{l}\text { One's potential } \\
\text { ability }\end{array}$ & $\begin{array}{l}\cdot \text { Confirmation of } \\
\text { creative energy of } \\
\text { complex }\end{array}$ & $\begin{array}{l}\text { - Confirmation of one's } \\
\text { energy contained in the } \\
\text { complex through } \\
\text { meditations }\end{array}$ \\
\hline & & $\begin{array}{l}15 \\
16\end{array}$ & $\begin{array}{l}\text { Individualizatio } \\
\mathrm{n} \text { promotion }\end{array}$ & $\begin{array}{l}\text { - Exploring resources } \\
\text { for individualization }\end{array}$ & $\begin{array}{l}\text { - Sharing the symbolic } \\
\text { meaning of } \\
\text { unconsciousness - } \\
\text { Raising consciousness } \\
\text { about inner negative } \\
\text { effects with positive } \\
\text { functions }\end{array}$ \\
\hline
\end{tabular}

\section{Results}

\subsection{Process of Changing Images of Oneself and Others}

In order to explore the process of changing the image of the participants themselves and others, the results of the sentence completion test were analyzed. The characteristic questionnaires of participants A, B, and C's sentence completion tests were as follows.

[Table 2] Pre- and Post-change of the Completion of Sentence Test

\begin{tabular}{|c|c|c|c|c|}
\hline Classification & $\begin{array}{l}\text { Questionnai } \\
\text { res }\end{array}$ & $\begin{array}{c}\text { Subjec } \\
\mathrm{t}\end{array}$ & Pre-change & Post- change \\
\hline \multirow{3}{*}{$\begin{array}{l}\text { Image of the } \\
\text { original } \\
\text { family }\end{array}$} & \multirow{3}{*}{$\begin{array}{l}\text { My mother } \\
\text { and I }\end{array}$} & A & are friends. & are comfortable friends. \\
\hline & & B & $\begin{array}{l}\text { are sad people who have not been able } \\
\text { to expand our abilities. }\end{array}$ & are warm people. \\
\hline & & $\mathrm{C}$ & sometimes resist each other. & miss each other. \\
\hline \multirow{3}{*}{$\begin{array}{l}\text { Image of } \\
\text { one's ability }\end{array}$} & \multirow{3}{*}{$\begin{array}{c}\text { When } \\
\text { something } \\
\text { strange } \\
\text { happened to } \\
\text { me, }\end{array}$} & A & What's going on? & I will solve it. \\
\hline & & $\mathrm{B}$ & What's this? & I take a look at it. \\
\hline & & $\mathrm{C}$ & I recover my senses. & $\begin{array}{l}\text { I solve it depending on the } \\
\text { situation. }\end{array}$ \\
\hline \multirow{6}{*}{$\begin{array}{l}\text { Image of } \\
\text { future and } \\
\text { goal }\end{array}$} & \multirow{3}{*}{ My future is } & A & hopeful. & hopeful. \\
\hline & & $\mathrm{B}$ & free to live. & I will be a counselor. \\
\hline & & $\mathrm{C}$ & I think I'm doing what I'm doing. & $\begin{array}{l}\text { I want to serve society with what } \\
\text { I'm doing now. }\end{array}$ \\
\hline & \multirow{3}{*}{$\begin{array}{l}\text { What I want } \\
\text { to do for the } \\
\text { rest of my } \\
\text { life is }\end{array}$} & A & $\begin{array}{l}\text { to make room to smile and relax with } \\
\text { my family. }\end{array}$ & living a happy life for myself. \\
\hline & & $\mathrm{B}$ & to join in making my mother happy. & making the person I meet smile. \\
\hline & & $\mathrm{C}$ & what I'm doing now. & sharing. \\
\hline
\end{tabular}


The results of the sentence completion test were analyzed according to three classifications with regard to the perspective of individualization: "image of the original family," "image of one's ability," and "image of future and goal." The analysis of the "image of the original family" shows a change from a negative image of the mother before the program to a positive image of acceptance and longing afterwards. In addition, the attitude towards one's ability and future also showed a positive change: prior to the program, this attitude was evasive and vague, whereas after the program, it became more independent and proactive. This shows that the participants' positive changes were made in the process of individualization.

\subsection{Analysis of Group Counseling Program Activity Materials and Verbatim Records}

In order to analyze the individualization process of the participants, the activity data and verbatim records for each session were analyzed. The results are as follows.

\subsubsection{Participant A}

Participant A depicted a bent tree (internal growth and achievement) as her symbol in the 1st and 2nd sessions. Trees are the most representative symbols of human history, signifying growth and maturity of consciousness [15]. Contrary to her strong will to grow and achieve her goals, a bent tree was seen as her ugly shadow. In the paintings of the 3rd and 4th sessions, in which her suppressed outer desires were idealized in the form of flowers, she was able to conscientize scenes from her childhood when her social persona wanted recognition and approval [16]. Through the paintings in the 5th and 6th sessions, she expressed her pent-up feelings of being abandoned by her fiancé, becoming conscious about the shadow of "worthless me" by projecting herself, a coward who turned a blind eye to an outcast friend as a child, onto him. And she was seen accepting herself by acknowledging the identification between her patients, to whom she offers impulsive caring, and herself, who was too afraid to be abandoned. Through complex exploration during the 9th and 10th sessions, she released her emotions bound to the feeling of guilt that she was unable to stop her brother from committing suicide and to the past when she sacrificed her own desires and needs in order to take care of her poor family from poverty, hunger, and death. During these sessions, the participant seemed to have gained an insight into her own complex and to have exhibited a curative power within herself. In the 15th and 16th sessions, through the portrayal of a cat and a stream, she became aware of her own curative powers with which she hoped to restore her feminine and independent spirit [16].

[Table 3] Major Works of the Participant A

Major works of the participant A by session




\subsubsection{Participant B}

In the 1 st and 2 nd sessions, she drew a young girl enjoying the cool breeze. As a symbol of comfortable memories of oneself as a child, it seems that the true self is revealed that it is beautiful and worth being loved [12] without being damaged. She seemed to be avoiding talking about her sister's death as a child, by changing the subject and laughing. In the 3rd and 4th sessions, she spoke about the difficulty in depiction through painting, and painted herself as smiling, hollow-eyed, which could be identified with the persona that avoids strong emotions with a kind, energetic smile in order to protect the "too-lethargic-to-feel-anything herself," who keeps refusing to find out what is going on inside her. In the 7th and 8th sessions, she was prompted to search for shadows through meditation, but avoided the procedure, saying "I can't think of anything," "I can't concentrate." However, she gave a long-winded explanation on "the appearance of floating in the air without being able to settle in one place, with roots exposed." She seemed to be defending the shadow from being revealed. She talked about the difficulties and struggles she experienced with relationships due to her lack of trust in the world and others, as she did not feel safe in her life. She also expressed discomfort in revealing herself in the group counseling sessions, but thanks to the support and encouragement of other participants, she opened up herself toward the end. In the 11th and 12th sessions, she complained of her tiring days at work, and although she said she was not able to participate due to such exhaustion, she still participated with her screen turned off. Toward the end of the session, she was seen holding back her desire to intervene and become the center of the conversation and confessing honestly about her feelings on the changes she was seeing in herself. In the 13th and 14th sessions, she referred to her complex as an ever-dependent parasite. She discovered her energy that allowed herself to keep trying until now in order to overcome the life she lived neglecting her true self and relying on her children like a parasite. In addition, her lengthy remarks were reduced compared to the initial sessions, and she was seen listening to feedback from counselors and group members instead of speaking unilaterally. During the 15th and 16th sessions, she painted the sun upon a hill; the hill is the symbol of creative energy and the god, and the almighty in the unconscious [15]. Natural objects are the most commonly used objects of art regardless of age, culture, and region, and the participant said that she felt as if she was re-given the energy she had as a child, and expressed her hope to finish her doctoral studies with passion and her determination to fulfill self-realization as a counselor.

[Table 4] Major Works of the Participant B

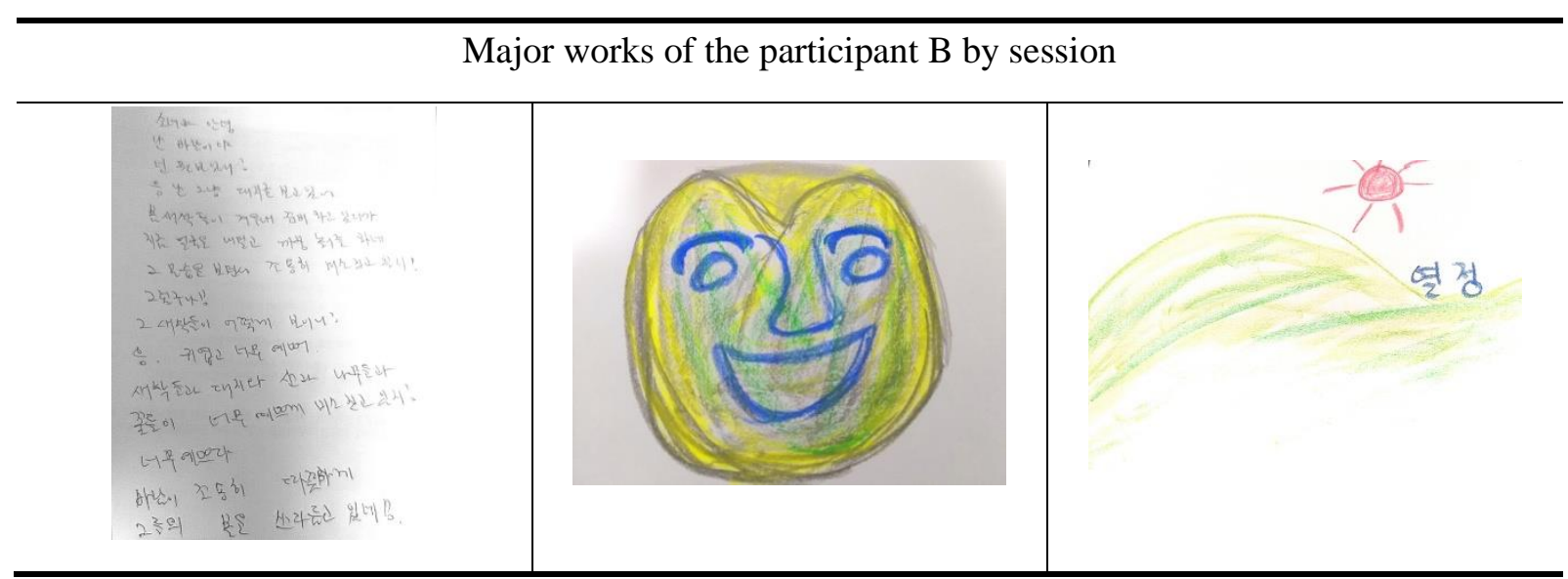

\subsubsection{Participant C}

She portrayed herself as a calm butterfly in the forest in the first and second sessions. Butterflies are seen as the symbol of finding true freedom from the reality or difficulties and of finding one's true self 
[16]. In the third and fourth sessions, she explored the idealized persona who pretends to be okay with a strong and bright smile on her face in response to her parents' high expectations and scolding, which continued since her childhood. In the fifth and sixth sessions, she painted an empty box, symbolizing the unconscious, signifying that she was unable to recognize the burdened emotions of her unconscious [16]. In the seventh and eighth sessions, she recalled a situation in which she could be seen only if she strongly asserted herself, and she identified with persona as a fighter who hoped to reveal and explore herself. In the ninth and tenth sessions, she symbolized herself through fairy tales, allowing herself to conscientize the shadows of the "competent" and "dominant" who wanted to be good at everything at work and also about the shadow of "being a nobody." In the 13th and 14th sessions, she became obsessed with psychological "victory" for self-satisfaction under the pretext of being a counselor at work, bringing it into consciousness that she had been neglecting the importance of being sincere and truly listening to her patients. In the 15th and 16th sessions, she learned the significance of her passion to exert her true power as a counselor and accepted the lack and desire to escape from herself as part of her process of self-realization.

[Table 5] Major Works of the Participant C

Major works of the participant $\mathrm{C}$ by session

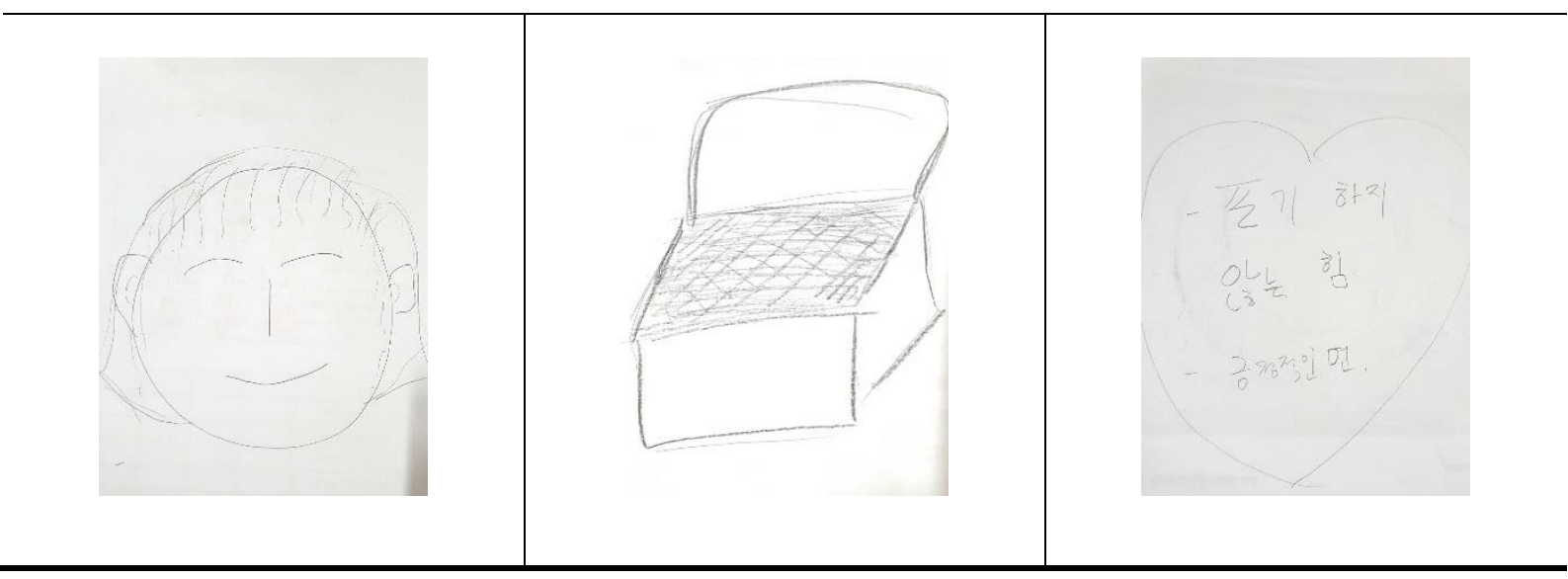

4. Conclusions and Suggestions

This study is a case study that examines the process of individualization of middle-aged women, focusing on analytical psychology. In the process of group counseling, the symbols shown in the meaningful works and the contents of each session were analyzed from the psychological perspective of analysis, and the process of individualization of each participant was examined through the sentence completion test.

As a result of this study, Participant A experienced the process of exploring his own perzona through works idealized with bent trees and flowers, which he wanted to suppress his desires and live in an outwardly bright way, and meeting his shadow connected to "unvalued me" in the past. In the second half, he connected the scenes that occurred in his unconsciousness, and showed a process of trying to restore himself by converting the guilt and complex of experience in the current event into the power of internal healing. B strongly resisted the loss of his desire to be loved in the early stages, recalling the scene of the death of a girl and her sister, and experienced inability to express honest feelings in the encounter with Persona and Shadow. However, in the second half, support and trust in group counseling showed an attempt to face his "life that could not settle without roots" shadow and complex, and in the final stage, he showed his inner change process by shaping himself as the sun rising on the hill. In the early days, $\mathrm{C}$ expressed himself as a calm butterfly in the forest and naturally went through in the 
process of consciousness of the unconsciousness of true freedom, exploring his persona as a strong person from childhood. And Perzona was strengthened and recognized his shadow that the needs of the "competent" and "ruler" were "nothing," and later showed the process of self-realization of life to restore authenticity as his counselor.

As a result of analyzing the sentence completion test with "attitude toward the original family, attitude toward one's ability, future and goal," A, B, and C were generally seen accepting and missing their mothers after negative feelings toward their mothers in advance. In addition, if one avoided one's problems or was biased toward life in advance about one's ability and attitude toward the future, the possibility for the future was changed hopefully with a subjective and active attitude afterwards. And in the change in attitude toward the post-mortem future [17] [18], the active attitude and hopeful results of life are in the same context as the results of this study.

These positive findings suggest that self-awareness and understanding are facilitating factors due to the occupational nature of the three study participants as counselors. They also had expectations and confidence in the effectiveness of the counseling, and their activities and sincerity in self-expression led their search deeply. Active group support from peer counselors and facilitating questions and feedback among each other promoted the entire process on a hard and lonely journey. Familiar media such as meditation, art, and writing also seem to have reduced resistance to exploring the unconscious.

Despite the effectiveness of this study, there are several limitations to generalizing its results, and some suggestions for subsequent studies are as follows:

First, there is a limitation that cannot be generalized due to the identical gender of all three participants in this study, i.e., middle-aged women. Subsequent studies need to further expand the sample to verify the effectiveness of the study;

Second, this study has the limitation with regard to the lack of objectivity because the consideration of symbols is not mechanically applicable to everyone. Subsequent studies need to be combined with qualitative and quantitative studies to compensate for shortcomings.

This study leads to understanding the process of personalization revealed through language expression, painting, and writing through group counseling. In addition, it is thought that it will be helpful to systematically understand how to convert by examining the transformation process based on the counselor's insight and analysis psychology.

\section{References}

[1] Lee Woo-kyung, Analysis of the relationship structure between stress caring self, and emotional well-being of middleaged women and the effectiveness of the program to promote mind caring, Ewha Womans University, Doctoral Dissertation, (2008)

[2] Lee Bu-young, Anima and Animus, Han Gil- sa, (2001)

[3] Sim Boram, A study on the relationship between the unconsciousness recognition process and the ego in Jung's analytical psychology, Dong Ui University, Master Thesis, (2019)

[4] Shin Kyung-seop, A Comparative Study on the Characterization of Calvin and the Personality of Jung, Hannam University, Doctoral Dissertation, (2005)

[5] Lee Bu-young, shadow, Han Gil- sa, (1999)

[6] Lee Bu-young, Analytical Psychology-C. G. Jung's thoughts on mind, A piece of work, (2011)

[7] Back Jaeun, A study of painting based on Carl Gustav Jung's personalization process, Konkuk University, Doctoral Dissertation, (2017)

[8] Park Sook-kyung, A Phenomenology Study on the Personalization Process of Middle-Aged Women who Experienced 
Depression, Daehan Theological Seminary \& University, Doctoral Dissertation, (2019)

[9] Park Tae-kyung, Development of programs for promoting self-realization of middle-aged women and verification of effectiveness, Daegu University, Doctoral Dissertation, (2019)

[10] Lee Yu-kyung, Jung and art psychotherapy, Proceedings of the Korean Arts Psychotherapy Association Conference, (2012), November 1-16; Daejeon, Korea.

[11] Yoo Seung-yeon, Kim Jung-ho, Kim Mirihye, Effects of Mindfulness Meditation on Symptoms of Depression, Anxiety, Stress, and Hwa-Byung among Middle-Aged Women with Hwa-Byung Disorders, Korean Journal of Health Psychology, (2014), Vol.19, No,1, pp.83-98, DOI: 10.17315/kjhp.2014.19.1.005

[12] Oh Jin-ryung, A study on the maternal complex and the process of individualization shown in "Kongji Patzzi", Pyeongtaek University, Doctoral Dissertation, (2012)

[13] J. M. Sacks, S. Levy, The sentence completion test, Projective psychology: Clinical approaches to the total personality, (1950), DOI: https://doi.org/10.1037/11452-011

[14] Yurina, The effect of self-realization collective art therapy on self-identity and self-concept in middle-aged age, A Gachon University's Graduate School of Special Treatment, Master Thesis, (2017)

[15] Jack Tracy, Symbolic story, Translated by Kim Byung-hwa, Dosol, (2007)

[16] E. Ackroyd, A Dictionary of Dream Symbols, Sterling Publishing, (1993)

[17] Choi Hye-jung, The process of personalization of middle-aged women through art therapy, Kon kuk University, Master Thesis, (2019)

[18] Hong Mi-kyung, From Kohut's perspective, Myongji University, Master Thesis, (2014) 